\title{
Replacement cost depreciation and cash flow requirements
}

\author{
R.C. Doenges \\ University of Texas at Austin, Austin, Texas \\ W.D. Hamman
}

Business School, University of Stellenbosch, Stellenbosch 7600, Republic of South Africa

I.J. Lambrechts*

Department of Business Economics, University of Stellenbosch, Stellenbosch 7600, Republic of South Africa

Received 14 February 1990; accepted 15 May 1990

\begin{abstract}
In this article a framework is developed to test whether depreciation based on replacement cost meets cash flow requirements. It also indicates both the extent to which depreciation based on replacement cost can be linked to depreciation based on historical cost and the factors which should be considered in the calculation of the ratio of replacement cost depreciation to historioal cost depreciation. These aspects are of importance to most enterprises and of particular importance to price-controlled enterprises. The most significant findings are that: there is no need to provide for backlog depreciation; additional depreciation needs only be provided to the extent that equity financing is used; and the ratio of replacement cost depreciation to historical cost depreciation is a function of the inflation rate, lives of assets and the applicable gearing ratios.

In hierdie artikel word 'n raamwerk ontwikkel om te toets of waardevermindering gebaseer op vervangingswaarde voldoende is vir kontantvloeibehoeftes. Daar word ook aangedui in welke mate waardevermindering gebaseer op vervangingswaarde gekoppel kan word aan waardevermindering gebaseer op historiese koste en watter faktore in aanmerking geneem moet word om die verhouding van vervangingswaarde-waardevermindering teenoor historiese kostewaardevermindering te bereken. Hierdie aspekte is cerstens van belang vir prysbeheerde ondernemings en bedryfstakke asook vir die meeste sake-ondernemings. Die belangrikste bevindings is: daar is geen noodsaaklikheid vir die voorsiening van agterstallige waardevermindering nie; addisionele waardevermindering hoef slegs voorsien te word in dieselfde mate as wat van finansiering met eie fondse gebruik gemaak is; en die verhouding van vervangingswaarde-waardevermindering teenoor historiese kostewaardevermindering is 'n funksie van die inflasiekoers, die leeftyd van bates en die toepaslike hefboomverhouding.
\end{abstract}

*To whom correspondence should be addressed.

\section{Imtroduction}

A question which often arises is whether or not sufficient provision has been made for additional depreciation (replacement cost depreciation less historical cost depreciation). In the case of a price-controlled enterprise, an over-provision for additional depreciation would result in prices or tariffs being too high. This is not so in the case of an enterprise which is in competition with others. In the latter case, the price or tariff is a function of free competition and an over-provision of replacement cost depreciation will have no effect on the consumer. The correct calculation of replacement cost depreciation is therefore very important for an undertaking which is not operating in a completely free market. A related aspect is the expression of replacement cost depreciation as a ratio of historical cost depreciation. This ratio is often used in price control formulae and in some cases critical values are also calculated. The practice is probably applied to indicate that the provision for additional depreciation is not excessive. The use of this ratio could result in erroneous calculations, as replacement cost depreciation is not a function of historial cost depreciation alone.

The objectives of this article are, firstly, to develop a framework for comparing replacement depreciation with actual cash flow requirements and, secondly, to indicate both the manner in which replacement cost depreciation could be linked to historial cost depreciation and the factors which should be taken into account if such an approach were to be followed.

When calculating depreciation based on replacement cost, certain problems are experienced, e.g. which indices to use in determining replacement costs and the calculation of the gearing adjustment. The solution of such problems is beyond the scope of this article.

\section{Terminology}

The replacement cost $\left(\mathrm{RC}_{\mathrm{ji}}\right)$ of asset $\mathrm{j}$ in year $\mathrm{t}$ is determined from the historical cost $\left(\mathrm{HC}_{\mathrm{jo}}\right)$ of asset $\mathrm{j}$ in the following way:

$\mathrm{RC}_{\mathrm{jt}}=\mathrm{HC}_{\mathrm{jo}}(1+\mathrm{I})^{\mathrm{t}}$

where

I = weighted average inflation rate per annum.

Historical cost depreciation $\left(H D_{j \mathrm{j}}\right)$ of asset $\mathrm{j}$ in year $\mathrm{t}$ is equal to the historical cost $\left(\mathrm{HC}_{\mathrm{jt}}\right)$ divided by the lifetime of an asset $\left(L_{j}\right)$, i.e.

$H D_{k}=\frac{H C_{j o}}{L_{j}}$

Replacement cost depreciation $\left(R D_{j t}\right.$ ) of asset $j$ in year $t$ (excluding backlog depreciation) is equal to the replacement 
cost $\left(R C_{j t}\right)$ of asset $j$ in year $t$ divided by the lifetime $\left(L_{j}\right)$ of the asset, i.e.

$R D_{\mathfrak{j}}=\frac{R C_{j t}}{L_{j}}$

From the above two formulae it follows that additional depreciation $\left(\mathrm{AD}_{\mathrm{j}}\right)$ of asset $\mathrm{j}$ in year $\mathrm{t}$; is equal to the difference between replacement 'cost depreciation and historical cost depreciation, excluding backlog depreciation, of asset $j$ in year $t$, i.e.

$A D_{j t}=R D_{j t}-H D_{j t}$

Backlog depreciation $\left(\mathrm{BD}_{\mathrm{j}}\right)$ of asset $\mathrm{j}$ in year $\mathrm{h}$ also known as recovery of under-depreciation, is equal to the accumulated depreciation based on replacement value in year $t$, calculated by dividing the latest replacement value by the lifetime, multiplying by the age (A) of the asset and then subtracting the sum of historical cost depreciation, additional depreciation and backlog depreciation to date, i.e.

$B D_{j t}=\left(\frac{R V_{j t}}{L_{j}} \times A\right)-\sum_{t=1}^{A}\left(H D_{j t}+A D_{j t}+B D_{j-1}\right)$

The formula for backlog depreciation could also be expressed in a simpler way. Backlog depreciation results (or is submitted to result) from the detrimental effect of inflation on accumulated depreciation. It is therefore equal to the inflation rate (I) multiplied by the accumulated depreciation of the previous year $\left(A C D_{\mathrm{j} 1-1}\right)$, which includes historical cost depreciation, additional depreciation and backlog depreciation, i.e.

$\mathrm{BD}_{\mathrm{jt}}=\mathrm{I} \times \mathrm{ACD}_{\mathrm{l}-1}$

The term updating depreciation $\left(\mathrm{UD}_{\mathrm{jt}}\right)$ is used in the context of this article to describe the total of additional depreciation and backlog depreciation where a system of replacement cost depreciation has not been in operation, i.e.

$\mathrm{UD}_{\mathrm{jt}}=A D_{\mathrm{jt}}+B D_{\mathrm{jt}}$

Updating depreciation is calculated in order to correct the accumulated depreciation based on replacement value (including backlog depreciation).

\section{The sufficlency of replacement cost depreciation}

The sufficiency of replacement cost depreciation is analysed by means of an example in which the following assumptions are made:

1. On 1 January of each year a new machine is acquired.

2. The purchase price of a machine increases by 12 per cent every year (for ease of argument it is assumed that price increases occur at the end of every year).

3. The lifetime and the depreciation period of a machine equals five years, after which replacement with an identical machine takes place. At the end of five years five machines are on hand, each with a different age, resulting in a situation of one hundred per cent diversity. A situation of complete or almost complete diversity is quite common in large production enterprises where assets are diversified in respect of type, lifetime, age, location and investment amount. Continuous replacement takes place instead of intermittent replacement. The cash required to replace operating capacity in year $t$ is exactly equal to replacement cost depreciation, i.e. no backlog depreciation is necessary.

4. Equity financing is assumed initially, i.e. no loan funds are used. This assumption is changed in Table 5.

5. The provision for updating depreciation is made in $\mathbf{1 9 . 5}$ so that a complete system of replacement depreciation can be introduced from 19.6 onwards.

6. The non-deductibility from taxable income of additional and backlog depreciation is ignored. It is

Table 1 Statistics of machines acquired and replaced

\begin{tabular}{ccccccc}
\hline & $\begin{array}{c}\text { Machine } \\
\text { acquired on } \\
1 / 1 \text { of } \\
\text { each year }\end{array}$ & $\begin{array}{c}\text { Cost of } \\
\text { machine at } \\
\text { beginning } \\
\text { of year }\end{array}$ & $\begin{array}{c}\text { Machine } \\
\text { scrapped at } \\
\text { beginning } \\
\text { of year }\end{array}$ & $\begin{array}{c}\text { Machines } \\
\text { on hand at } \\
\text { year-end }\end{array}$ & $\begin{array}{c}\text { Accumulated } \\
\text { historical cost } \\
\text { of machines } \\
\text { on hand }\end{array}$ & $\begin{array}{c}\text { Accumulatod } \\
\text { historical cost } \\
\text { depreciation of } \\
\text { machines on hand }\end{array}$ \\
\hline 19.1 & A & 100.0 & & $\mathrm{~A}$ & 100.0 & 20.0 \\
19.2 & $\mathrm{~B}$ & 112.0 & & $\mathrm{~A}+\mathrm{B}$ & 212.0 & 62.4 \\
19.3 & $\mathrm{C}$ & 125.4 & & $\mathrm{~A}+\mathrm{B}+\mathrm{C}$ & 337.4 & 129.9 \\
19.4 & $\mathrm{D}$ & 140.5 & & $\mathrm{~A}+\mathrm{B}+\mathrm{C}+\mathrm{D}$ & 477.9 & 225.5 \\
19.5 & $\mathrm{E}$ & 157.4 & & $\mathrm{~A}+\mathrm{B}+\mathrm{C}+\mathrm{D}+\mathrm{E}$ & 635.3 & 352.6 \\
19.6 & $\mathrm{~A}_{1}$ & 176.2 & $\mathrm{~A}$ & $\mathrm{~B}+\mathrm{C}+\mathrm{D}+\mathrm{E}+\mathrm{A}$, & 711.5 & 394.9 \\
19.7 & $\mathrm{~B}_{1}$ & 197.4 & $\mathrm{~B}$ & $\mathrm{C}+\mathrm{D}+\mathrm{E}+\mathrm{A}_{1}+\mathrm{B}_{1}$ & 796.9 & 442.3 \\
19.8 & $\mathrm{C}_{1}$ & 221.1 & $\mathrm{C}$ & $\mathrm{D}+\mathrm{E}+\mathrm{A}_{1}+\mathrm{B}_{1}+\mathrm{C}_{1}$ & 892.6 & 495.4 \\
19.9 & $\mathrm{D}_{1}$ & 247.6 & $\mathrm{D}$ & $\mathrm{E}+\mathrm{A}_{1}+\mathrm{B}_{1}+\mathrm{C}_{1}+\mathrm{D}_{1}$ & 999.7 & 554.8 \\
19.10 & $\mathrm{E}_{1}$ & 277.3 & $\mathrm{E}$ & $\mathrm{A}_{1}+\mathrm{B}_{1}+\mathrm{C}_{1}+\mathrm{D}_{1}+\mathrm{E}_{1}$ & 1119.6 & 621.3 \\
\hline
\end{tabular}

1. Historical cost of machines purchased to date less historical cost of machines scrapped to date.

2. Calculated from toul line in Table 2: Historical cost depreciation less historical cost of machine(s) being replaced. 
therefore assumed that the cash flow effect of the provision for additional and backlog depreciation and that of historical cost depreciation are similar in the sense that the cash flow is equal to the provision.

7. The straight-line method of depreciation is used.

The example is illustrated in Tables 1-4. In Table 1 the statistics relating to the machines acquired and replaced are summarised. It shows the historical cost of each machine, the machines on hand and scrapped, and the accumulated historical cost and historical cost depreciation of the machines on hand. The calculations in the table are explained by means of notes to the table.

In Table 2 the historical cost depreciation of the machines on hand is calculated in detail. The calculation of updating depreciation in $\mathbf{1 9 . 5}$ is illustrated in Table 3. The adjustment for the additional and backlog depreciation not provided for 19.1-19.5 and 19.2-19.5 respectively appears under the heading 'updating depreciation' and amounts to 176.1. This amount is calculated as in Table 3a (based on the formulae in 2 above):

From the calculations in Table $3 a$ it is clear that additional depreciation not provided for in the period 19.1-19.5 amounts to 106.4 and the backlog depreciation not provided for in the period 19.2-19.5 to 69.7 , the total being 176.1 which is the total in column $\mathrm{g}$ of Table 3 .

The calculation of replacement cost depreciation in 19.6, the first year after the implementation of replacement cost depreciation, appears in Table 4 . In this table a clear differentiation between additional and backlog depreciation is made. To evaluate whether or not the provision for total

Table 2 Calculation of historical cost depreciation of the machines on hand

\begin{tabular}{|c|c|c|c|c|c|c|c|c|c|c|c|c|}
\hline \multicolumn{13}{|c|}{ End of year } \\
\hline Begiming & & Historical & & & & & & & & & & \\
\hline year & Mechine & $\cos t$ & 19.1 & 19.2 & 19.3 & 19.4 & 19.5 & 19.6 & 19.7 & 19.8 & 19.9 & 19.10 \\
\hline 19.1 & $\mathbf{A}$ & 100.0 & 20.0 & 20.0 & 20.0 & 20.0 & 20.0 & & & & & \\
\hline 19.2 & B & 112.0 & & 22.4 & 22.4 & 22.4 & 22.4 & 22.4 & & & & \\
\hline 19.3 & C & 125.4 & & & 25.1 & 25.1 & 25.1 & 25.1 & 25.1 & & & \\
\hline 19.4 & D & 140.5 & & & & 28.1 & 28.1 & 28.1 & 28.1 & 28.1 & & \\
\hline 19.5 & $\mathbf{E}$ & 157.4 & & & & & 31.5 & 31.5 & 31.5 & 31.5 & 31.5 & \\
\hline 19.6 & $\mathbf{A}_{1}$ & 176.2 & & & & & & 35.2 & 35.2 & 35.2 & 35.2 & 35.2 \\
\hline 19.7 & $\mathbf{B}_{\mathbf{1}}$ & 197.4 & & & & & & & 39.5 & 39.5 & 39.5 & 39.5 \\
\hline 19.8 & $\mathbf{C}_{1}$ & 221.1 & & & & & & & & 44.2 & 44.2 & 44.2 \\
\hline 19.9 & $D_{1}$ & 247.6 & & & & & & & & & 49.5 & 49.5 \\
\hline 19.10 & $\mathbf{E}_{1}$ & 277.3 & & & & & & & & & & 55.5 \\
\hline Total & & & 20.0 & 42.4 & 67.5 & 95.6 & 127.1 & 142.3 & 159.4 & 178.5 & 199.9 & 223.9 \\
\hline
\end{tabular}

Table 3 Calculation of replacement depreciation in 19.5

\begin{tabular}{|c|c|c|c|c|c|c|c|}
\hline & $\begin{array}{l}\text { Historical } \\
\text { cont of } \\
\text { machines }\end{array}$ & $\begin{array}{c}\text { Replacement } \\
\text { cost of } \\
\text { machines at end } \\
\text { of } 19.5^{1)}\end{array}$ & $\begin{array}{c}\text { Historical } \\
\text { cost depreciation } \\
\text { in } 19.5\end{array}$ & $\begin{array}{l}\text { Percentage } \\
\text { of historical } \\
\text { cost } \\
\text { written off }\end{array}$ & $\begin{array}{l}\text { Accumulated } \\
\text { historical cost } \\
\text { depreciation }\end{array}$ & $\begin{array}{l}\text { Accumulated } \\
\text { depreciation } \\
\text { based on } \\
\text { replacement cost }\end{array}$ & $\begin{array}{l}\text { Updating } \\
\text { depreciation } \\
\text { in } 19.5^{2}\end{array}$ \\
\hline & 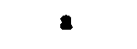 & $\mathbf{b}$ & $c=a \div 5$ & d & $e=\operatorname{sxd}$ & $f=b x d$ & $8=f-c$ \\
\hline$A$ & 100.0 & 176.2 & 20.0 & 100 & 100.0 & 176.2 & 76.2 \\
\hline $\mathbf{B}$ & 112.0 & 176.2 & 22.4 & 80 & 89.6 & 141.0 & 51.4 \\
\hline c & 125.4 & 176.2 & 25.1 & 60 & 75.2 & 105.7 & 30.5 \\
\hline D & 140.5 & 176.2 & 28.1 & 40 & 56.2 & 70.5 & 14.3 \\
\hline \multirow[t]{2}{*}{$\mathbf{E}$} & 157.4 & 176.2 & 31.5 & 20 & 31.5 & 35.2 & 3.7 \\
\hline & 635.3 & 881.0 & 127.1 & & 352.5 & 528.6 & 176.1 \\
\hline
\end{tabular}

1. $100(1.12)^{3}$

2. Updating depreciation in $\mathbf{1 9 . 5}=$

Accumulated replecement cost depreciation less accumulated historical cost depreciation =

additional depreciation not provided in 19.1-19.5 and backlog depreciation not provided in 19.2-19.5.

Accurmulated historical cost depreciation 19.5

Updating depreciation year 19.5

Accumulated replacement cost depreciation 19.5

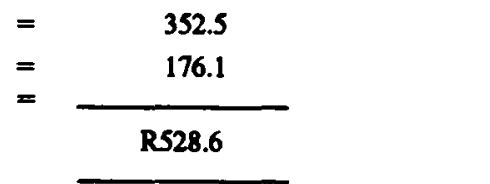


Table 3a Calculation

\begin{tabular}{|c|c|c|c|c|c|}
\hline Year & $H D_{n}{ }^{1}$ & $\mathrm{RD}_{\mathrm{n}}{ }^{2}$ & $A D_{n}{ }^{3}$ & $\mathrm{ACD}_{n}{ }^{4}$ & $\mathrm{BD}_{n}{ }^{3}$ \\
\hline 19.1 & 20.0 & 22.4 & 2.4 & 22.4 & - \\
\hline 19.2 & 42.4 & 50.2 & 7.8 & 75.3 & 2.7 \\
\hline 19.3 & 67.5 & 84.3 & 16.8 & 168.6 & 9.0 \\
\hline 19.4 & 95.6 & 126.0 & 30.4 & 314.8 & 20.2 \\
\hline \multirow[t]{2}{*}{19.5} & 127.1 & 176.1 & 49.0 & 528.7 & 37.8 \\
\hline & Toul & $19.1-19.5$ & 106.4 & Total 19.2-19.5 & 69.7 \\
\hline
\end{tabular}

1. Total historical cost depreciation in relevant year. See Table 2.

2. (RV per machine at end of year $x$ number of machines) $+L_{j}$ e.g. for 19.3: $140.5 \times 3$

\section{5}

3. $R D_{n}-H D_{n}$ of specific year.

4. $\begin{array}{rlrl}\mathrm{ACD}_{n} & =\sum_{t=1}^{\mathrm{n}}\left(\mathrm{RD}_{\mathrm{n}}+\mathrm{BD}_{\mathrm{n}},\right. & \begin{array}{l}\text { where } \mathrm{n} \text { is the specific } \\ \text { year, e.g. 19.3: }\end{array} \\ & =(22.4+50.2+84.3) & +(2.7+9.0) \\ & = & 156.9 & +11.7 \\ & = & 168.6 & \end{array}$

5. I $\quad$ × $A C D_{n-1}, e .8 .19 .4=0.12 \times 168.6=20.2$

where

HD $=$ total historical cost depreciation in year $t$

$\mathrm{RD}_{n} \quad=$ total replacement cost depreciation in year $\mathrm{t}$

$A D_{n} \quad=$ toul additional depreciation in year $t$

$\mathrm{ACD}_{\mathrm{n}}=$ toal accumulated depreciation in year $\mathrm{t}$

$\mathrm{BD}_{\mathrm{T}} \quad=$ tosal backlog depreciation in year $\mathrm{L}$

replacement cost depreciation is sufficient for replacement, an analysis is made in terms of cash flow in Table 5. The assumption of 100 per cent equity financing is relaxed and the effect of different financing mixes on cash flow is investigated. The cash inflow consists of historical cost depreciation, additional depreciation and backlog depreciation (the latter where applicable). The cash outflow consists of the purchase price of the replacement investment.

If loan capital is partially used to finance a machine, an adjustment for gearing has to be made in respect of additional and backlog depreciation. Provision should only be made for the higher replacement cost of that portion financed by equity capital. In the case of loan capital with a guaranteed source. provision for inflation is built into the interest rate over the longer term and the source automatically supplies its portion of the higher replacement cost (assuming a fixed financing ratio). If the loan capital ratio (debt/assets) is indicated by $D$, the cash inflow consists of:

$H D_{n}=(1-D)\left(A D_{n}+B D_{n}\right)$

and the cash outflow (application) amounts to:

(1 - D)(Purchase price of new machine) + repayment of previous loan
Nine different combinations of cash inflows (sources) are analysed in Table 5 for 19.6. On the applications side only one combination (ratio) of financing is assumed, i.e. 70 per cent loan financing. It is assumed that loans are repaid on a straight-line basis over five years (interest is excluded). The redemption is equal to 70 per cent of the historical cost of the assets. In column 1 the difference between available and required funds is calculated and in column $m$ it is expressed as a percentage of total funds required (column $\mathbf{k}$ ).

The following conclusions are drawn from Table 5:

1. There is only one situation where there is no overrecovery of funds, i.e. where the financing assumption of the sources equals the financing assumption of the applications (70 percent loan capital) and no backlog depreciation is provided.

2. The larger the difference between the equity percentage of the sources and the equity percentage of the applications, the larger is the over-recovery.

3. The larger the percentage backlog taken into account, the larger the over-recovery.

4. The surplus can be calculated by applying the following formula:

$\left(E_{\text {s }}-E_{A}\right) A D_{\mathbf{R}}+B D_{\mathbf{R}}$

where:

$E_{2}=$ equity percentage of the sources, and

$E_{A}=$ equity percentage of the applications (30\% throughout)

e.g. the combination of 70 per cent equity and 70 per cent backlog:

$(0.70-0.30) 55.1+29.6=51.7$

and the combination of 30 per cent equity and no backlog:

$(0.30-0.30) 55.1+0=0$

The ratlo replacement cost depreciation: historical cost depreciation

This ratio is to a large extent a function of acquisition dates (age), lives and specific price increases (inflation), as is clear from Table 6 which is based on the same information as Table 1 (see the previous section) and which summarises the situation after five years. The following conclusions are drawn from the table:

1. The older a machine, i.e. the shorter the remaining life, the higher is the ratio of additional depreciation to historical cost depreciation. If the lifetime of an asset increases, this ratio would also increase.

2. The higher the price increase of the assets, the higher the ratio will be and vice versa.

3. The ratio (r) of additional depreciation $\left(A D_{j t}\right)$ : historical cost depreciation $\left(\mathrm{HD}_{\mathrm{jl}}\right)$ for a specific 
machine can be derived from the following formula:

$$
r=\frac{A D_{k}}{H D_{j}}=(1+)^{L_{j}-R_{j t}}-1
$$

where:

$$
\begin{array}{ll}
\mathbf{L}_{j} & =\text { lifetime of machine } j \\
\mathbf{R}_{\mathbf{k}} & =\text { remaining life of machine } j \text { in year } t \\
\mathbf{L}_{j}-\mathbf{R}_{\mathbf{k}} & =\text { age of machine } \mathrm{j} \text { in year } \mathbf{t}
\end{array}
$$

and the other symbols have the usual meaning, e.g. where the age is three years (machine $C$ ), the ratio in Table 6 is as follows

$$
(I+0.12)^{5.2}-1=1.39-1=0.39
$$

In line with the conclusion in the previous section, no provision has been made for backlog depreciation which is unneccessary in the situation of complete diversity assumed in the example. Even if a situation of incomplete diversity of the type, age or lifetime of assets existed, there would be no need for backlog depreciation. The latter necessitates continued replacement rather than large replacements on a discontinuous basis.

The total historical cost depreciation $\left(H D_{n}\right)$ can be calculated from the following formula:

$H D_{n}=\sum_{j=1}^{k} \sum_{i=1}^{\sum} \quad H D_{j}=\frac{H C_{j 1}}{L_{j}} \frac{(1+D)^{L i}-1}{I}$

where:

$\mathrm{HC}_{\mathrm{j} 1}=$ historical cost of machine $\mathrm{j}$ in $\mathbf{1 9 . 1}$

$\mathbf{k}=$ number of machines

and the other symbols have the usual meaning.

\begin{tabular}{|c|c|c|c|c|c|c|c|c|}
\hline Mxchine & $\begin{array}{l}\text { Historical } \\
\text { cost of } \\
\text { machines }\end{array}$ & $\begin{array}{l}\text { Replacement } \\
\text { cont of } \\
\text { machines at } \\
\text { end of } 19.6^{1)}\end{array}$ & $\begin{array}{c}\text { Historical } \\
\text { cost depre- } \\
\text { cinion in } \\
19.6\end{array}$ & $\begin{array}{l}\text { Additional } \\
\text { depreciation } \\
\text { in } 19.6\end{array}$ & $\begin{array}{c}\text { Percentage } \\
\text { of historical } \\
\text { cont wriuen } \\
\text { off }\end{array}$ & $\begin{array}{l}\text { Accumulated } \\
\text { depreciation } \\
19.5 \text { (sce } \\
\text { Table } 3 \\
\text { column g) }\end{array}$ & $\begin{array}{c}\text { Accumulated } \\
\text { depreciation } \\
\text { based on re- } \\
\text { placement } \\
19.6^{2)}\end{array}$ & $\begin{array}{l}\text { Badklog } \\
\text { depre- } \\
\text { ciation? }\end{array}$ \\
\hline & $\mathbf{a}$ & b & $c=a+5$ & $d=(b-2)+5$ & e & f & $g=b x e$ & $h=g-c-f-g$ \\
\hline B & 1120 & 197.4 & 224 & 17.1 & 100 & 141.0 & 197.4 & 16.9 \\
\hline C & 125.4 & 197.4 & 25.1 & 14.4 & 80 & 105.7 & 157.9 & 127 \\
\hline D & 140.5 & 197.4 & 28.1 & 11.4 & 60 & 70.5 & 118.4 & 8.4 \\
\hline $\mathbf{E}$ & 157.4 & 197.4 & 31.5 & 8.0 & 40 & 35.2 & 79.0 & 4.3 \\
\hline \multirow[t]{2}{*}{$\mathbf{A}_{\mathbf{1}}$} & 176.2 & 197.4 & 35.2 & 4.2 & 20 & - & 39.4 & - \\
\hline & 711.5 & 987.0 & 142.3 & 55.1 & & 3524 & 592.1 & 42.3 \\
\hline
\end{tabular}

The total replacement depreciation $\left(R D_{T}\right)$ is equal to:

$$
\mathrm{RD}_{\mathrm{n}}=\sum_{j=1}^{\mathbf{k}} \sum_{\mathrm{i}=1}^{\mathbf{k}} \quad \mathrm{RD}_{\mathrm{j}}=H \mathrm{C}_{\mathrm{jl}} \quad\left(1+\mathrm{I}^{\mathrm{Li}}\right.
$$

$$
\begin{aligned}
& \text { and the ratio: } \\
& \begin{aligned}
\frac{R D_{n}}{H D_{n}} & =\frac{H C_{j 1}}{H C_{j 1}} \frac{(1+I)^{L j}}{(1+I)^{L j}-1} \\
& =\frac{L_{j}}{I} \\
& \frac{L_{j}}{I(1+I)^{L j}-1}
\end{aligned}
\end{aligned}
$$

Table 4 Calculation of replacement cost depreciation in 19.6

1. $100(1.12)^{6}$

2. Accumulated deprociation besed on replecement con 19.5 (Twble 3) $\quad 528.6$

Less A scrupped

Opening balance 19.6 (column f)

Historical cost depreciztion 19.6 (column c) 142.3

Additional depreciation 19.6 (column d) 55.1

Bectlog deprecistion 19.6 (column b) $\quad 42.3$

Accumulred replacemen con depreciation (column \&)

3. Bactlog deprecintion = Accumulated depreciation a end

of previous year (column $\mathrm{f}) \times$ inflation rate

$=3524 \times 0.12$

$=42.3$ 


$$
\text { The formula } \frac{(1+I)-1}{I(1+I)^{L j}}
$$

is equal to the present value (PV) of an annuity and

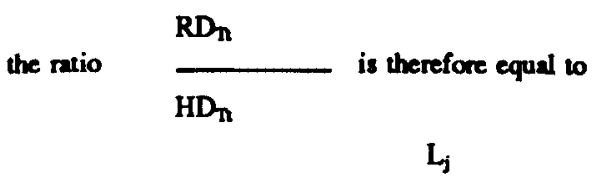

PV of an mnuity over $L$ periods at an inflation race of 1

In Table 6, the ratio $\frac{R D_{\mathrm{Tt}}}{H D_{\mathrm{n}}}$ amounts to $\frac{5}{3.605}=1.39$

Following the derivation of this formula a table could be compiled for different lifetimes (L) and inflation rates (I) as in Table 7.

From this table it is clear that the longer the lifetime and the higher the inflation rate, the higher

$$
\text { the ratio } \frac{R D_{\mathrm{n}}}{H D_{\mathrm{T}}}
$$

If the assumption regarding 100 per cent equity financing is relaxed and different gearing ratios are assumed the situation will change as in Table $8(I=15 \%)$.

The higher the gearing ratio, the lower

the ratio $\frac{R D_{\mathrm{T}}}{H D_{\mathrm{n}}}$

because of the lower 'responsibility' of the suppliers of equity capital.

\section{Practical implications of findings}

The major findings of this article are that there is no need for backlog depreciation, that additional depreciation should only be provided to the extent that equity financing takes place and that

the ratio $\frac{R D_{\mathbf{n}}}{H D_{\mathrm{T}}}$

is a function of the inflation rate, the life of assets and the

Table 5 The sufficiency of replacement cost depreciation (assuming different ratios of financing) to replace fixed assets (assuming only a seventy per cent debt ratio) in 19.6

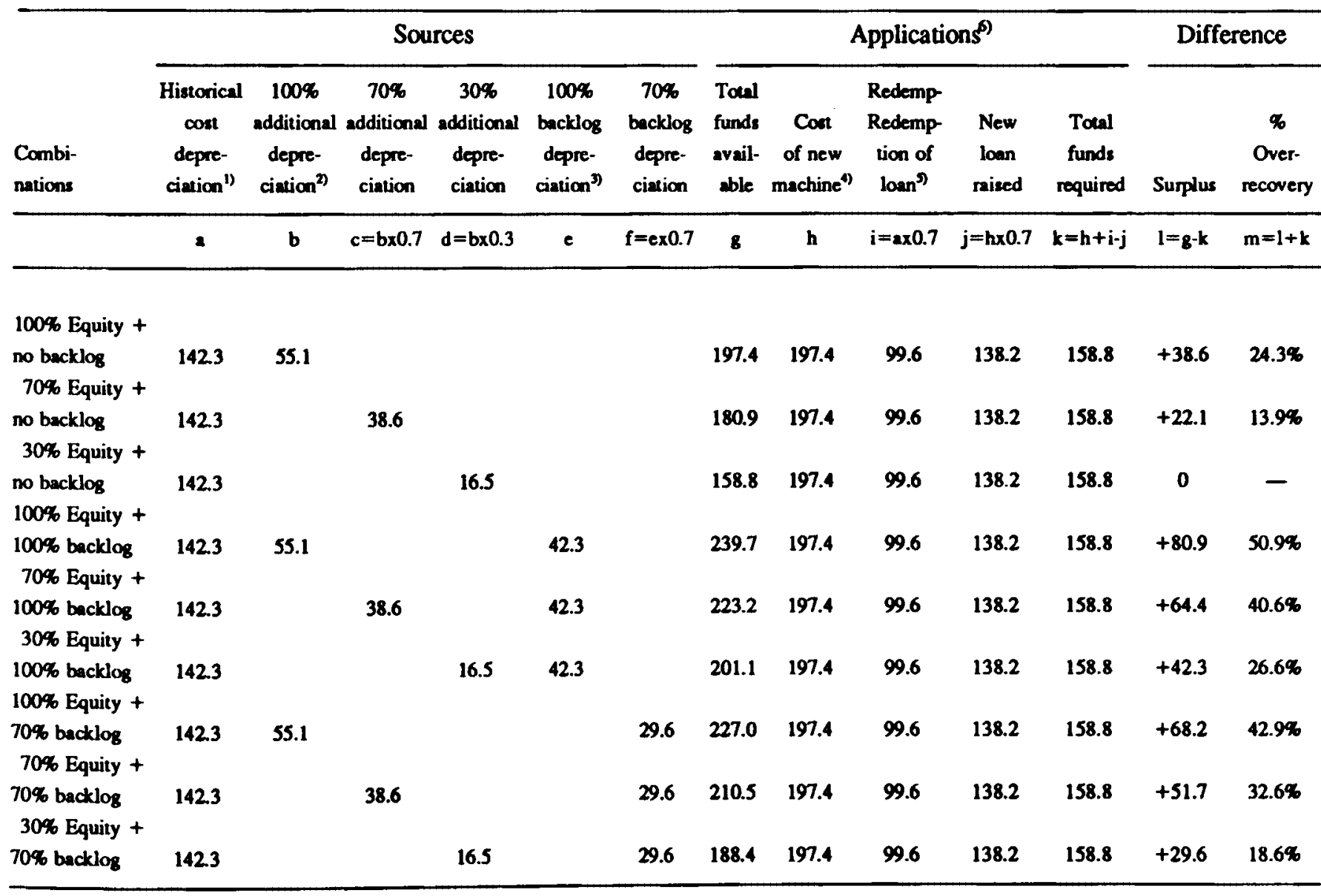

1. Table 4 column c

2 Table 4 column d

3. Table 4 column $h$

4. Table 4 column b

5. Loan is repaid in five equal instalments (exclude interest)

6. Funds required for new machine and redemption of old loan, less new funds obtained 
Teble 6 Calculation of ratio additional depreciation: historical cost depreciation in 19.5

\begin{tabular}{|c|c|c|c|c|c|c|c|}
\hline Machine & $\begin{array}{l}\text { Purchase } \\
\text { decte }\end{array}$ & $\begin{array}{c}\text { Purctuse } \\
\text { price }\end{array}$ & $\begin{array}{l}\text { Historical } \\
\text { deprecinion }\end{array}$ & $\begin{array}{l}\text { Replecement } \\
\text { cost }\end{array}$ & $\begin{array}{l}\text { Replacement } \\
\text { cont } \\
\text { depreciation }\end{array}$ & $\begin{array}{l}\text { Additional } \\
\text { depreciation }\end{array}$ & $\begin{array}{l}\text { Additional } \\
\text { depreciation: } \\
\text { historical cost } \\
\text { depreciation }\end{array}$ \\
\hline a & b & c & $d=c+5$ & $e=c(1.12)^{20}$ & $f=e+5$ & $g=f-d$ & $h=g \div d$ \\
\hline $\mathbf{A}$ & 19.1 & 10000 & 20.00 & 176.23 & 35.25 & 15.25 & 0.76 \\
\hline B & 19.2 & 112.00 & 22.40 & 176.23 & 35.25 & 12.85 & 0.57 \\
\hline C & 19.3 & 125.44 & 25.09 & 176.23 & 35.25 & 10.16 & 0.40 \\
\hline D & 19.4 & 140.49 & 28.10 & 176.23 & 35.24 & 7.14 & 0.25 \\
\hline \multirow[t]{2}{*}{$\mathbf{E}$} & 19.5 & 157.35 & 31.47 & 176.23 & 35.24 & 3.77 & 0.12 \\
\hline & & 636.28 & 127.06 & 881.15 & 176.23 & 49.17 & 0.39 \\
\hline
\end{tabular}

= Lifetime (5 years) less remaining life of mechine

Table 7 Lifetime (L) and inflation rates (I)

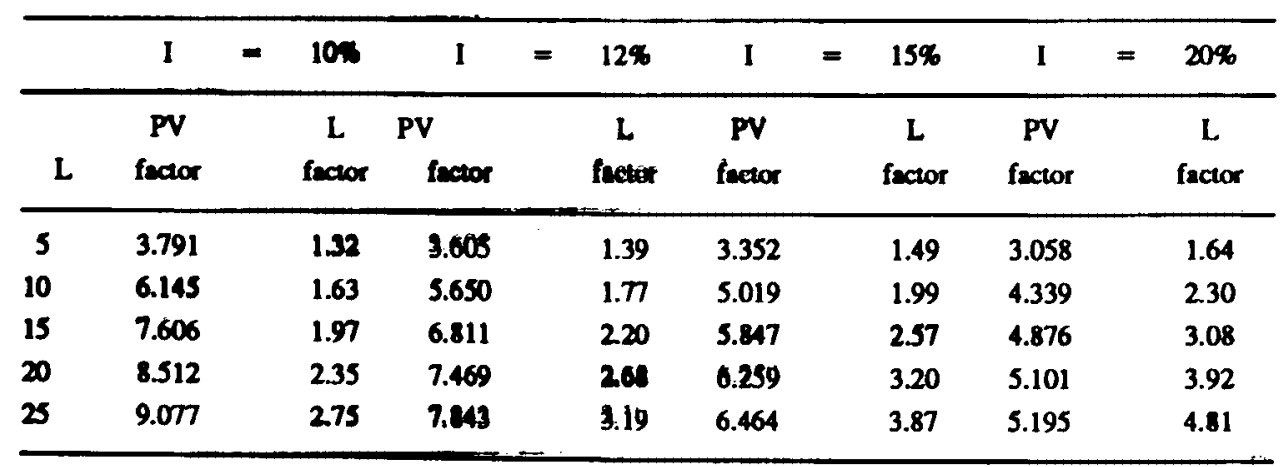

relevant gearing ratios. These findings are of great importance in the financial analysis of annual reports in which replacement depreciation has been provided. At present it is, to a large extent the parastatals which provide for replacement depreciation. Compared to private undertakings they have an advantage in that they do not pay Ificome tax.

Finally, a word of caution - the results and findings of the article should be viewed in the light of the underlying assumptions. 